\title{
Movement of Crude Oil in an Experimental Spill on the SEEDS Simulated Pipeline Right-of-way, Fort Norman, N.W.T.
}

\author{
G. PETER KERSHAW ${ }^{1}$
}

(Received 12 July 1989; accepted in revised form 28 November 1989)

\begin{abstract}
The Studies of the Environmental Effects of Disturbances in the Subarctic (SEEDS) experimental spill was conducted on a simulated pipeline right-of-way and trench. A total of $3273 \mathrm{~L}$ of Norman Wells crude oil was released over a $24 \mathrm{~h}$ period at a depth of $100 \mathrm{~cm}$ in a simulation of a rupture from a subsurface pipeline. Absorptive qualities of the surface vegetation and organic soil layers in an undisturbed forest produce rates of flow and area of contamination values much lower than the SEEDS experiment. Furthermore, the area of contamination $\left(672.75 \mathrm{~m}^{2}\right)$ was greater than experiments in which the amount of oil and rates of pumping were larger. This resulted from the presence of surface water, a depressed mineral soil-dominated simulated pipeline trench, a cleared right-of-way and slow pumping rates. The SEEDS experiment was a more valid analogue of crude-oil spills associated with a buried pipeline in a subarctic environment.
\end{abstract}

Key words: oil spill, crude oil, hydrocarbon spill, piepline, Subarctic, corridor, disturbance

RÉSUMÉ. Le déversement expérimental réalisé dans le cadre del'étudeSEEDS (Studies of the Environmental Effects of Disturbances in the Subarctic) a eu lieu sur le trajet et la tranchée simulés d'un oléoduc. Une quantité de 3273 litres de pétrole brut de Norman Wells a été déversée au cours d'une période de $24 \mathrm{~h}$ à une profondeur de $100 \mathrm{~cm}$, pour simuler la rupture d'un oléoduc souterrain. Les qualités absorptives de la végétation de surface et des couches de sol organique dans une forêt non perturbée, ont donnée des taux d'écoulement et des valeurs de contamination de la surface beaucoup plus bas que dans l'expérience SEEDS. De plus, la zone contaminée $\left(672,75 \mathrm{~m}^{2}\right)$ était plus grande que celle où avaient été effectués des déversements expérimentaux dans lesquels la quantité de pétrole et les taux de pompage étaient plus importants. Cela était dû à la présence d'eau de surface, au fait que la tranchée simulée de l'oléoduc était dans une dépression et contenait un sol riche en minéraux, au fait que le passage avait été débroussaillée et que les taux de pompage étaient bas. L'expérience SEEDS était une reproduction plus valide des déversements de pétrole brut associés à un oléoduc enfoui dans le sol dans un environnement subarctique.

Mots clés: déversements de pétrole, pétrole brut, déversements d'hydrocarbure, oléoduc, subarctique, tranchée simulée, perturbation

Traduit pou: le journal par Nésida Loyer.

\section{INTRODUCTION}

The subsurface mode of the Norman Wells-Zama Lake pipeline (the Norman Wells Project) may well be selected for additional mainland crude-oil pipelines from the Beaufort Sea or Arctic Islands. If there were a rupture of a buried pipeline, then crude-oil spills would occur into the active layer and eventually migrate upward onto the pipeline rightof-way. Studies of simulated, thaw-season crude-oil spills in arctic and subarctic environments have been limited primarily to those occurring onto the soil surface in undisturbed forests (Wein and Bliss, 1973; Charles and Mackay, 1974; Mackay et al., 1974; Jenkins et al., 1978; Westlake et al., 1978; Hutchinson, 1980; Collins, 1983). Two methods of oil application have been used: the spraying of a uniform coating on the vegetation and soils (Wein and Bliss, 1973; Hutchinson et al., 1974; Walker et al., 1978), and localized point spills pumped directly onto the surface (Hutchinson and Freedman, 1975; Jenkins et al., 1978). It has been recognized that surface applications by spraying do not closely simulate an oil spill from a pipeline break in terms of intensity, movement of oil or vegetation contamination (Hutchinson and Freedman, 1978; Kershaw and Kershaw, 1986). Although surface point spills more closely simulate an aboveground pipeline failure, they may not provide a valid analogue for a subsurface spill where subsequent spread of oil within the soil may give rise to different impacts. Furthermore, current subsurface line construction practices result in the disruption of the surface organic layer and exposure of the mineral-dominated soil component (Wishart, 1988). In subarctic areas with permafrost, this surface disturbance combined with the effects of right-of-way clearing results in surface subsidence due to thickening of the active layer and a loss of near-surface ground ice (Viereck, 1982; Evans et al., 1988).

Point-origin experimental surface spills have been conducted in permafrost-affected areas with a tree cover and understory vegetation intact (Charles and Mackay, 1974; Mackay et al., 1975; Johnson et al., 1980). Subsurface spreading of oil, as a result of downward percolation, resulted in a more extensive area affected (Mackay et al., 1974; Jenkins et al., 1978; Collins, 1983). Mackay and others (1974) found that oil in the moss layer was only visible in areas where it was flowing too fast for the capacity of the moss layer to absorb it. They further concluded that oil, following a surface spill, drains from the moss and the visible spill area becomes approximately half the size of the total contamination zone.

\section{OBJECTIVES}

The main objective of this study was to determine how oil would behave under conditions that would prevail during a small subsurface crude-oil spill from a buried pipe within a transport corridor in permafrost-affected terrain.

\section{LOCATION}

The experiment was initiated at the Studies of the Environmental Effects of Disturbances in the Subarctic (SEEDS) site, $10 \mathrm{~km}$ north of Fort Norman, Northwest Territories (Fig. 1). The experimental area was in a decadent Picea mariana stand at least $\mathbf{2 8 0}$ years old. Permafrost underlies the site and a number of simulated transport corridor disturbances have been under investigation since their creation in 1985 (Evans $\mathrm{et}$ al., 1988; Kershaw, 1988; Gallinger and Kershaw, 1989). 


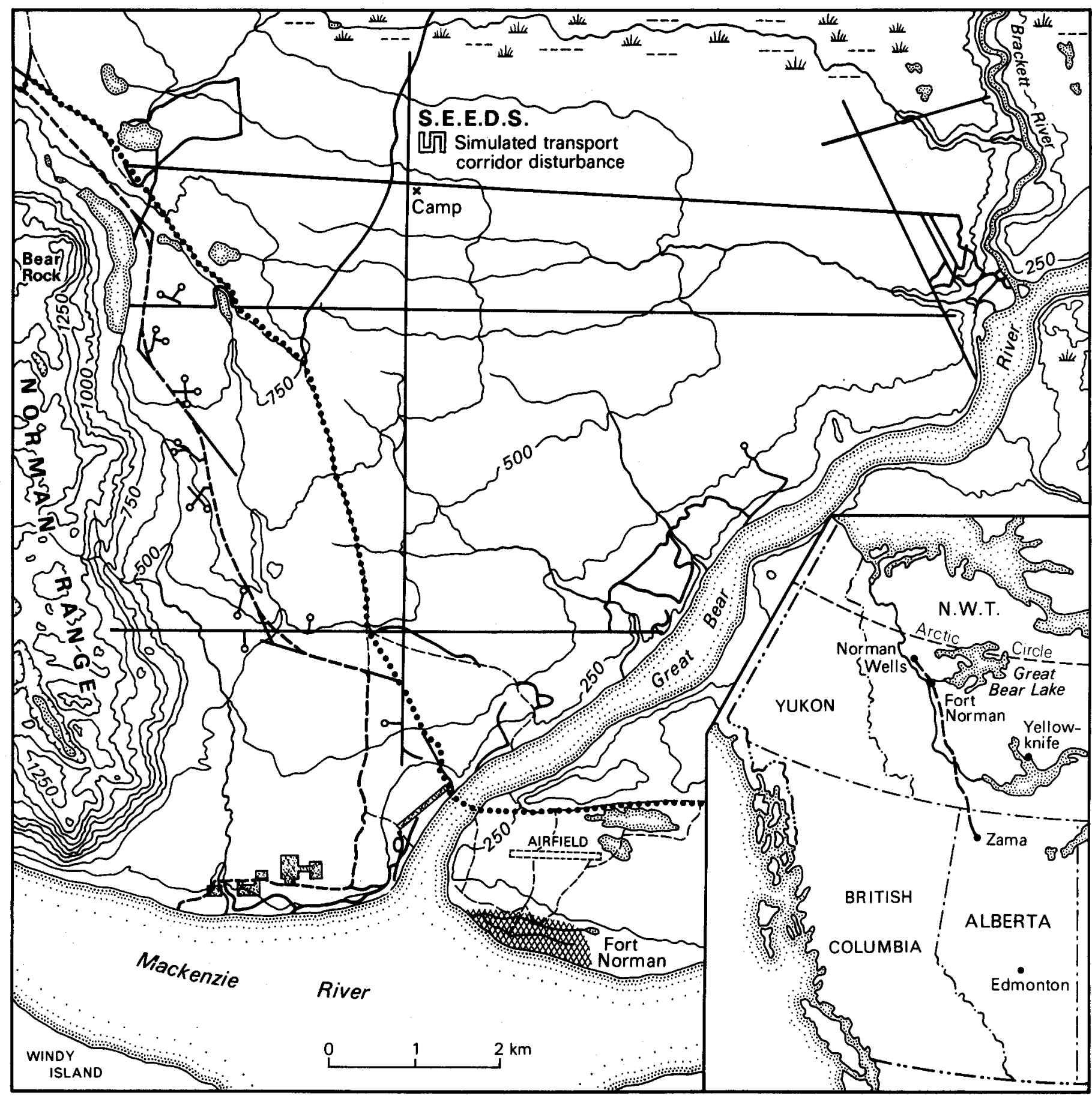

Norman Wells Project

Crude - oil pipeline $\quad-----$ Original winter road

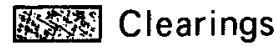

Seismic lines and

Realigned winter road

Contour interval 125 feet abandoned trails

FIG. 1. The SEEDS simulated transport/pipeline corridor is $10 \mathrm{~km}$ north of Fort Norman, N.W.T., on a NNE-facing slope of $1.5^{\circ}$ in an upland Picea marianadominated forest.

\section{METHODS}

\section{Spill Initiation}

An elevated catwalk network (total length of approximately $310 \mathrm{~m}$ in September 1988 and extended to $535 \mathrm{~m}$ in June 1989) was installed on the site of the spill to ensure unimpeded access and a minimum of trampling disturbance during the life of the experiment (Fig. 2). Over a period of 24 $\mathrm{h}, 3.27 \mathrm{~m}^{3}$ ( $3273 \mathrm{~L}$, or 20 imperial barrels) of Norman Wells crude oil was pumped directly into an open-ended, $100 \mathrm{~cm}$ long segment of a $30.5 \mathrm{~cm}$ diameter pipe (Table 1) buried at a depth of $100 \mathrm{~cm}$ in an existing simulated pipeline trench. The 


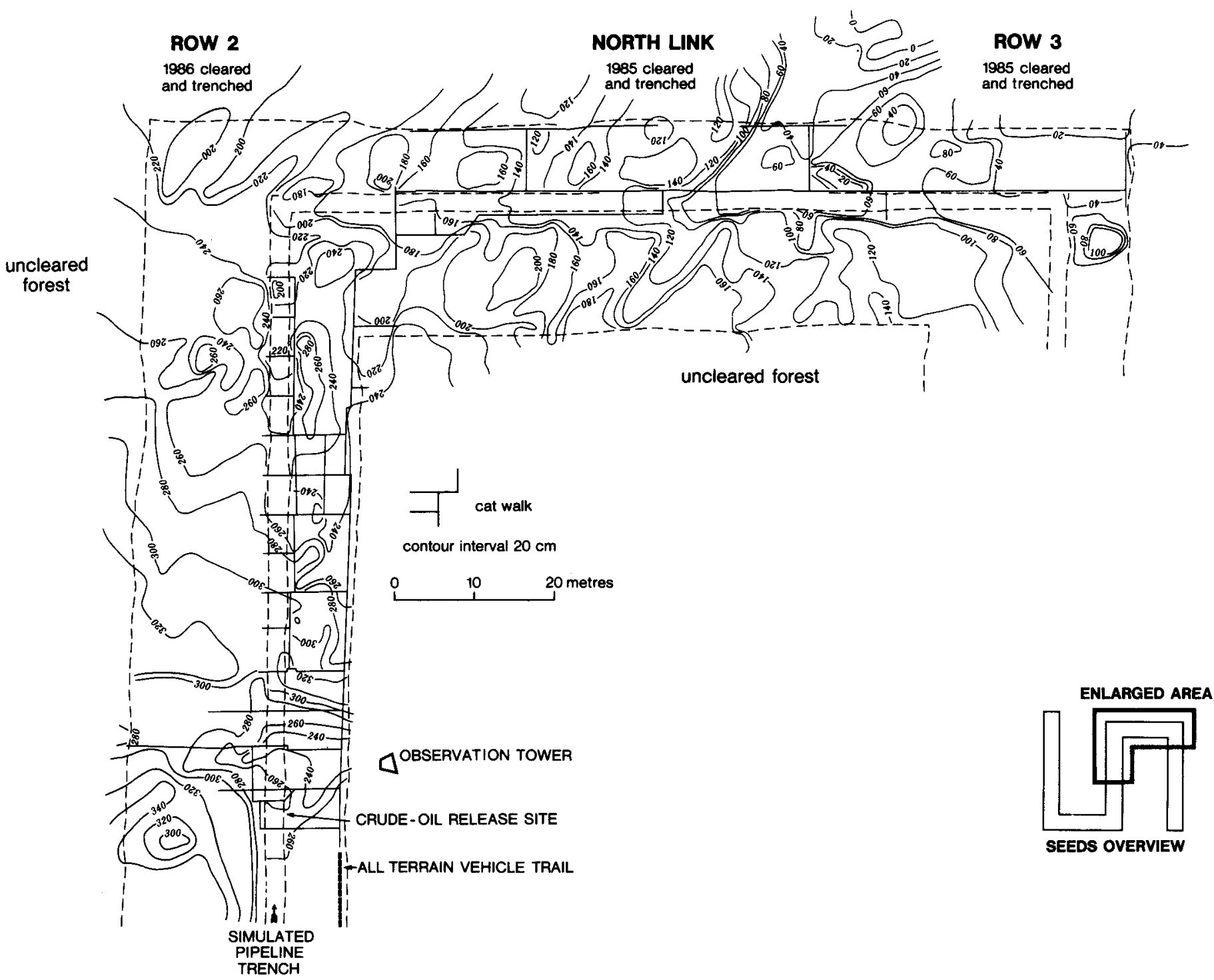

FIG. 2. The site of the experiment was a cleared right-of-way (ROW) with north-south and east-west oriented trenched portions. A catwalk was installed to reduce disturbance due to monitoring activities.

trench was $2 \mathrm{~m}$ wide and extended the length of the cleared right-of-way, 14 to $16 \mathrm{~m}$ from one side and $9 \mathrm{~m}$ from the other. This portion of the simulated pipeline right-of-way extends down the $1-2^{\circ}$ slope for approximately $90 \mathrm{~m}$, then turns at $90^{\circ}$ and runs across the slope for $100 \mathrm{~m}$ (Fig. 2). The pump employed to extract and move the oil from the barrels was a Honda G200 Oil Alert with a Honda Trash Pump WT20 jacket attached to $5 \mathrm{~cm}$ diameter hoses. Oil was allowed to escape from the buried pipe commencing at 15:00 h on 28 August 1988 (Table 1).

Consequently, unlike previously reported experiments (Charles and Mackay, 1974; Mackay et al., 1975; Johnson et al., 1980): 1) The oil was slowly released $-136.4 \mathrm{~L}^{-1}$ (simulating a leak at a level below detection on modern pipelines). 2) The release point was $70 \mathrm{~cm}$ below the moss surface on the adjacent right-of-way within the mineral-dominated active layer (simulating a break in a buried pipeline). 3) The point of release was within a linear, mineral soil-dominated depression (such as would occur in association with a buried pipeline). 4) The simulated pipeline trench was within a cleared right-of-way (similar to an operating pipeline right-of-way at least two years following construction). 5) The right-of-way location was selected to have sections parallel and normal to the general slope trend. (As with typical northern transport corridors, surface runoff could be trapped and channelled along the depressed simulated pipeline trench.)

\section{Spill Morphology}

The three-dimensional geometry of the spill was monitored using a coring and dowel/lath system adapted from Jenkins et al. (1978). A sampling grid was established at the time of the surface spill with $1 \mathrm{~m}$ cells in a $50 \times 17 \mathrm{~m}$ plot (encompassing the area downslope and $5 \mathrm{~m}$ above the point of the spill). However, shortly after the commencement of the pumping operation it was apparent that the area of the spill was going to be larger than expected. Accordingly, a new grid varying from $1 \times 1 \mathrm{~m}$ to $5 \times 5 \mathrm{~m}$ cells (depending on the topography and the presence of oil) was installed (Fig. 2). During the 1989 field season grid points were determined for the perimeter of the spill. These points provided permanent survey markers for monitoring the oil's movement. Wooden laths were inserted at known points to the maximum thaw 
TABLE 1. Quantities and rates of flow of an experimental crude-oil spill, SEEDS, Fort Norman, N.W.T.

\begin{tabular}{|c|c|c|c|c|c|c|c|c|c|}
\hline \multicolumn{2}{|c|}{$\begin{array}{l}\text { Date \& time } \\
\text { (hhmm) }\end{array}$} & Quantity (L) & $\begin{array}{l}\text { Area of spill } \\
\left(\mathrm{m}^{2}\right)\end{array}$ & $\begin{array}{l}\text { Cumulative area } \\
\text { of spill }\left(\mathrm{m}^{2}\right)\end{array}$ & $\begin{array}{c}\text { Average } \\
\text { concentration } \\
\text { of spill }\left(\mathrm{L} \cdot \mathrm{m}^{-2}\right)\end{array}$ & $\begin{array}{c}\text { Hours since } \\
\text { initiation }(h)\end{array}$ & $\begin{array}{c}\text { Increment } \\
\text { increase of spill } \\
\left(\mathrm{m}^{2} \cdot \mathrm{h}^{-1}\right)\end{array}$ & $\begin{array}{l}\text { Concentration } \\
\text { change } \\
\left(\mathrm{L} \cdot \mathrm{m}^{-2} \cdot \mathrm{h}^{-1}\right)\end{array}$ & $\begin{array}{c}\text { Increment } \\
\text { in concentration } \\
\text { change } \\
\left(\mathrm{L} \cdot \mathrm{m}^{-2} \cdot \mathrm{h}^{-1}\right)\end{array}$ \\
\hline \multicolumn{10}{|c|}{1988} \\
\hline 28 Aug & 1530 & 164 & 33.5 & 33.5 & 4.9 & 2.50 & 13.4 & 1.96 & 1.96 \\
\hline 28 Aug & 2130 & 818 & 41.75 & 75.25 & 10.87 & 8.50 & 6.96 & 1.28 & 1.81 \\
\hline 29 Aug & 0900 & 818 & 13.5 & 88.75 & 9.22 & 20.00 & 1.17 & 0.46 & 0.8 \\
\hline 29 Aug & 1300 & 2134 & 1.75 & 90.5 & 23.58 & 24.00 & 0.44 & 0.98 & 5.9 \\
\hline 30 Aug & 1300 & 3273 & 96.0 & 186.5 & 17.55 & 48.00 & 4.0 & 0.37 & 0.73 \\
\hline 31 Aug & 1930 & 3273 & 43.0 & 229.5 & 14.26 & 78.50 & 1.41 & 0.18 & 0.47 \\
\hline 1 Sept & 1600 & 3273 & 28.75 & 258.25 & 12.67 & 99.00 & 1.4 & 0.13 & 0.62 \\
\hline 2 Sept & 1300 & 3273 & 9.75 & 268.0 & 12.21 & 120.00 & 0.46 & 0.10 & 0.58 \\
\hline \multicolumn{10}{|c|}{1989} \\
\hline June & & 3273 & 404.75 & 672.75 & 4.86 & 281 days & 0.06 & $\mathrm{n} / \mathrm{a}$ & $\mathrm{n} / \mathrm{a}$ \\
\hline
\end{tabular}

$\mathrm{n} / \mathrm{a}$ : not appropriate to provide a value due to the extended time period involved.

depth, where they were left for sufficient time to absorb oil from the soil. Oil on the wood was easily detected by sight and smell (Charles and Mackay, 1974; Collins, 1983). In this manner, the depth of oil penetration and its horizontal extent were monitored until 2 September at 13:00 h, when the last measurements were taken at the time of the camp being closed. In February numerous snow pits were excavated in an effort to determine the extent of the spill; however, without complete removal of the snowpack it proved impossible to plot the spill margin along its entire length. During the spring of 1989 a final detailed topographic survey was completed for the area of the spill and its extent was measured during the plane table survey. Further checking was conducted at the end of August 1989.

\section{Soils and Oil Characteristics}

Soil sampling was conducted prior to the spill initiation to determine moisture content. Thirty samples were taken from 15 sites within the trench and right-of-way. Sampling was stratified by depth $(0-15 \mathrm{~cm}$ and $15-30 \mathrm{~cm})$. Ideally volumetric water content would be most appropriate; however, due to the high water and peat content and the technique/tools employed, it was not possible to consistently extract a known volume of soil. Consequently moisture content was expressed on a dry weight basis following air drying to stable weights. Soils were Gleysolic Turbic Cryosol-silt loams, with an average clay and fine sand content of approximately $20 \%$ each, while the remaining $60 \%$ was composed of silt (Kershaw and Evans, 1987; Evans et al., 1988).

Most previous Canadian studies have also used Norman Wells crude oil (Table 2). The similarity in viscosity and specific gravity therefore reduces the possibility of variability in crude-oil characteristics affecting the results and therefore permits more direct comparison of the SEEDS spill to previous work.

\section{RESULTS}

As a result of saturated soil conditions ( $>100 \%$ within the top $30 \mathrm{~cm}$ ) and the fine texture of the soils at the site, little oil was confined to the active layer. Oil could not be absorbed or infiltrate the soil. Confining pressures due to overburden were insufficient to confine the oil within the active layer, and so it was forced to the soil surface along the discontinuity provided by the pump hose where it passed through the soil to the buried pipe segment. Upon reaching the surface, oil flowed along the topographically low areas of the site (the simulated pipeline trench and existing depressions and swails; Fig. 2). The subsurface portion of the spill was localized to an

TABLE 2. A comparison of point-origin, experimental crude-oil spills conducted in subarctic environments

\begin{tabular}{|c|c|c|c|c|c|c|c|c|c|}
\hline & $\begin{array}{l}\text { Road } \\
\text { allowance }\end{array}$ & Forest & Forest & Forest & Forest & Forest & Forest & Forest & $\begin{array}{l}\text { Simulated } \\
\text { pipeline } \\
\text { right-of-way }\end{array}$ \\
\hline Season & summer & summer & summer & winter & winter & spring & summer & winter & summer \\
\hline Volume $\left(\mathrm{m}^{3}\right)$ & 0.72 & 0.72 & 10.12 & 0.90 & 1.00 & 1.26 & 7.57 & 7.57 & 3.27 \\
\hline Area affected $\left(\mathrm{m}^{2}\right)$ & 100.3 & 118.2 & 400.0 & 26.0 & 49.0 & 128.5 & 303.0 & 188.0 & 672.75 \\
\hline Concentration $\left(\mathbf{L} \cdot \mathrm{m}^{-2}\right)$ & 7.2 & 6.1 & 25.3 & 34.6 & 20.4 & 9.8 & 25.0 & 41.0 & 4.86 \\
\hline Coverage $\left(\mathrm{m}^{2} \cdot \mathrm{m}^{-3}\right)$ & 139.31 & 164.17 & 39.53 & 28.89 & 49.00 & 102.00 & 40.03 & 24.83 & 205.54 \\
\hline Surface slope $\left(^{\circ}\right)$ & 2.0 & ND & ND & 2.0 & 2.0 & 2.0 & 4.0 & 4.0 & 1.5 \\
\hline Pumping rate $\left(\mathrm{L} \cdot \mathrm{min}^{-1}\right)$ & 114.67 & 72.00 & 84.33 & 112.50 & 285.71 & 36.00 & 170.00 & 170.00 & 2.84 \\
\hline Oil temperature $\left({ }^{\circ} \mathrm{C}\right)$ & ND & ND & 26 & -20 & 40 & 15 & 57 & 57 & 16 to 23 \\
\hline Air temperature $\left({ }^{\circ} \mathrm{C}\right)$ & ND & ND & 22 & -20 & -20 & 15 & 25 & -5 & 16 to 23 \\
\hline Crude-oil type & N.W. & N.W. & N.W. & N.W. & N.W. & N.W. & P.B. & P.B. & N.W. \\
\hline Specific gravity & 0.83 & 0.83 & 0.81 & ND & ND & ND & 0.89 & 0.89 & $\mathrm{ND}$ \\
\hline Date initiated (ddmmyy) & 0772 & 150772 & 080773 & 250274 & 270274 & 160574 & 140776 & 260276 & 280888 \\
\hline Source & \multicolumn{2}{|c|}{ Charles and Mackay, 1974} & \multicolumn{4}{|c|}{ Mackay et al., 1980; Mackay et al., 1975} & \multicolumn{2}{|c|}{ Johnson et al., 1980} & This study \\
\hline
\end{tabular}

P.B. - Prudhoe Bay crude oil; N.W. - Norman Wells crude oil; ND — no data.

Note: several values had to be estimated based on reported data.

Conversion values: $1 \mathrm{~m}^{3}=220$ Imperial gallons $=6.11$ Imperial barrels; $1 \mathrm{~m}^{3}=264$ U.S. gallons $=8.39$ U.S. barrels. 
area of less than $1 \mathrm{~m}^{3}$. The size of the aboveground portion of the spill increased rapidly as the oil was released; then, after $24 \mathrm{~h}$ the rate of increase in area declined (Table 1). Initially the oil occupied low areas. Then it pooled and remained relatively fixed in its extent and concentration (Table 1). Within the first $24 \mathrm{~h}$ after the initiation of pumping it had occupied $13.45 \%$ of its ultimate extent (Fig. 4). Within $24 \mathrm{~h}$ of the cessation of pumping, the end of the spilling operation, it had occupied $27.7 \%$ of its final area. By the fifth day after commencement of pumping, the spill occupied $268 \mathrm{~m}^{2}$ and the rate of change in area had dropped from $13.4 \mathrm{~m}^{2} \cdot \mathrm{h}^{-1}$ to 0.46 $\mathrm{m}^{2} \cdot \mathrm{h}^{-1}$ (Table 1).

Concentration of oil was only estimated based upon the amount released and the areal extent of the contamination zone (Table 1). As such it represents only a gross estimate on which the rate of change in concentration values were based. At the initiation of pumping the rate of change in concentration was the highest, since the oil moved quickly along the confining drainage-ways at a rate of $1.96 \mathrm{~L} \cdot \mathrm{m}^{-2} \cdot \mathrm{h}^{-1}$. This was the maximum rate, and it declined to $0.8 \mathrm{~L} \cdot \mathrm{m}^{-2} \cdot \mathrm{h}^{-1}$ at the time when pumping ceased. Over the next four days it declined to $0.58 \mathrm{~L} \cdot \mathrm{m}^{-2} \cdot \mathrm{h}^{-1}$ when observation ceased. Between 29 and 30 August the rate of change in the concentration increased to $5.9 \mathrm{~L}^{-2} \cdot \mathrm{h}^{-1}$ when it sperad out to cover a flat area on the rightof-way (Fig. 3). During the next four days the rate of change in area remained relatively constant as the oil spread onto the trench of the North Link (Fig. 2). Much of the new area added to the spill between September and June was only patchily covered by blobs of concentrated oil residue. Within this portion of the spill were numerous areas without visible oil or with only a light coating of oil.

In February 1989 an attempt was made to delineate the spill margin. This necessitated snow removal, and it proved impractical to precisely follow the spill margin and therefore accurately determine the areal extent of the spill. Since the sites of snow trench excavation were at or near the June margins of the spill, much of its areal extent must have been set by mid-winter. This $404.75 \mathrm{~m}^{2}$ was a $151 \%$ increase in area over the September values.

\section{DISCUSSION}

An assessment of the behaviour of crude oil in the active layer was not possible since the oil came to the surface upon release. A possible method of insuring that, at least initially, the oil remains in the soil is to conduct the spill using an identical approach but in the early winter when the soil surface is frozen, thus preventing its spread to the surface.

In September it was expected that any further increase in area would be small, with much of it occurring along the topographically depressed simulated pipeline trench. This expectation was based upon the behaviour of other experimental crude-oil spills (Table 2) as well as the slow rates of increase observed five days following initiation of the SEEDS spill. With $60.2 \%$ of the spill area being added subsequent to the September measurement (Fig. 4), it is apparent that major differences exist between the SEEDS spill and other experimental crude-oil spills.

It is possible to compare the mid-growing season spill conducted by Charles and Mackay (1974) on a cleared, mineral-dominated road allowance near Norman Wells to the SEEDS spill. All other experiments were conducted in forests with no human-induced disturbances present. The SEEDS spill produced a lower concentration $\left(4.87 \mathrm{vs} .7 .2 \mathrm{~L} \cdot \mathrm{m}^{-2}\right)$, while its area was 6.7 times that of the road allowance spill (Fig. 3, Table 2). Some of the difference may be due to the SEEDS spill volume being almost 4.5 times that used on the road allowance. The saturated condition of the road allowance at the time of the spill was probably similar to the SEEDS simulated pipeline trench; however, the presence of flowing water (even the small amount on the SEEDS site) facilitated the spread of the oil. The slower rates of areal increase occurred once the oil at the SEEDS site flowed onto the cleared right-of-way, with its intact surface organic layer producing flows reduced to rates similar to those experienced by Collins (1983) in a subarctic forest site near Fairbanks.

If one considers area-to-volume ratios, it is apparent that the SEEDS spill was the highest of the experimental spills conducted in the Subarctic (Fig. 3). This is particularly significant since three of those with lower ratios were for volumes of two or more times that of the SEEDS spill (Table 2). However, these experiments were conducted on forested sites. In addition, the spills conducted by Charles and Mackay (1974), with the exception of a summer forest spill conducted by Mackay et al. $(1980,1975)$, involved smaller volumes than the SEEDS spill (Table 2). With these low volumes it is difficult to compare among experiments, and Mackay et al. (1975) maintain that spill area is not directly proportional to spill volume. If the SEEDS crude-oil volume is plugged into the formula of Mackay et al. (1975) [1], it predicts that the area will be $153.6 \mathrm{~m}^{2}$, or $518.65 \mathrm{~m}^{2}$ smaller than the actual area. However, the $672.25 \mathrm{~m}^{2}$ area at 4.4 times the predicted value is within the error range of Mackay et al. (1975), stated to be a factor of 3 to 6 .

Spill area $\left(\mathrm{m}^{3}\right)=53.5\left(\text { spill volume }\left(\mathrm{m}^{3}\right)\right)^{0.89} \quad$ [1]

The relatively large area of the SEEDS spill and its consequently high area-to-volume ratio $\left(205.58 \mathrm{~m}^{2} \cdot \mathrm{m}^{-3}\right)$ or coverage (Table 2) is a result of the channelizing of flow along the mineral soil-dominated simulated pipeline trench and naturally occurring drainage swails on the cleared right-of-way. As a consequence of the movement of the oil, it differed from the road alignment used by Charles and Mackay (1974) and produced a larger area-to-volume ratio (205.58 vs. 139.3 $\mathrm{m}^{2} \mathrm{~m}^{-3}$ ). Furthermore, the SEEDS spill concentration was much lower than all other experimental spills, regardless of season or site characteristics (Table 2). These characteristics are presumably due in large measure to absorptive ability of the moss/lichen mat and soil humus layer in both the Alaskan and Norman Wells studies, where release was conducted into an undisturbed forest (Mackay et al., 1974, 1975, 1980; Jenkins et al., 1978; Johnson et al., 1980; Collins, 1983).

Another factor is the rate at which the oil was released. At 2.8 L.min ${ }^{-1}$ the SEEDS spill was several magnitudes below the next highest rate (Table 2). With slower pumping rates the movement of the oil front should have been relatively slow, maximizing its potential for absorption into the organic surface horizons and moss/lichen layer of the vegetation. However, the SEEDS spill had a relatively low area-to-volume ratio, confirming the low absorption potential of the simulated pipeline trench.

Comparing rates of area increase on the experimental Alaskan summer spill and the SEEDS spill, it is evident that the former rapidly achieved its final size (i.e., $88 \%$ within six days) (Figs. 4 and 5). The SEEDS spill was only $39.8 \%$ of its ultimate 


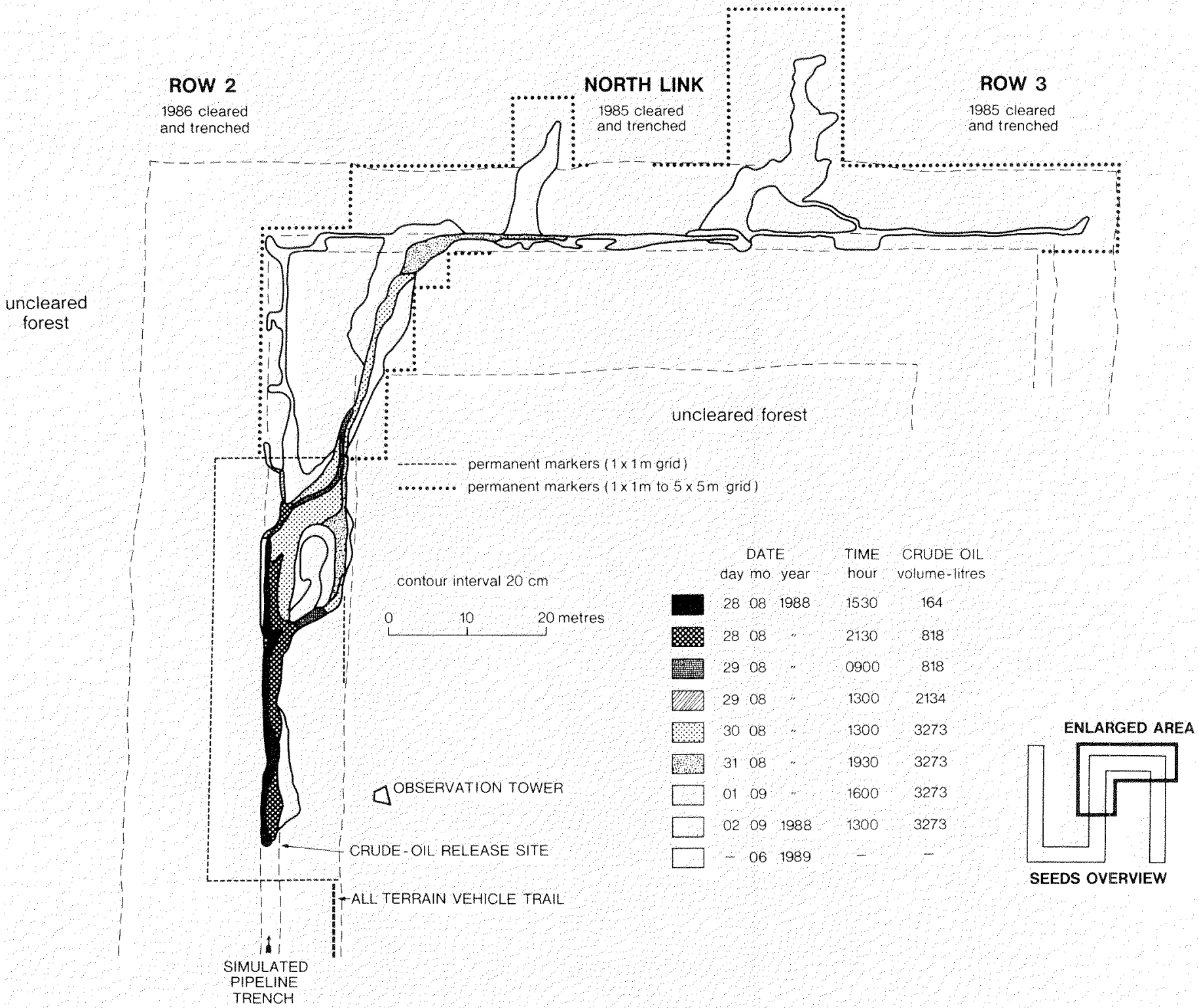

FIG. 3. Initially the oil flowed along the depressed trench portion of ROW 2 until channelled off this area by naturally occurring linear depressions. The oil then moved across the cleared portion of the right-of-way, through a corner of forest, onto the North Link and back into the depressed simulated pipeline trench By spring the following year it had expanded via naturally occurring depressions into the edge of the uncleared forest, where its extent stabilized for a total of $672.75 \mathrm{~m}^{2}$.

area within five days. Again the differences in absorptive capacities of the materials in contact with the oil would help explain this situation.

\section{CONCLUSIONS}

The SEEDS spill originated at $100 \mathrm{~cm}$ depth and became a surface spill as a result of the active layer's inability to absorb the oil as it was emitted. This was to be expected in finegrained, saturated soils. However, should the surface be frozen, a condition prevailing during early winter, then the oil may well be trapped within the still unfrozen active layer.

Similarities exist between the SEEDS spill and previously conducted surface, point-origin, experimental crude-oil spills. The areal extent of the oil was controlled by: 1) low volume but continually flowing water in a shallow channel; 2 ) to- pographically depressed areas and their degree of interconnectedness; and 3) low absorptive ability of the surfaces in contact with the oil (including moisture content of the substrate).

The SEEDS crude-oil spill deviated from other experimental spills in that: 1) The oil front moved rapidly over saturated mineral soil-dominated surfaces, conditions expected over a buried pipeline. 2) Average concentration values were low, while area-to-volume ratios were high, suggesting that less oil covers larger areas when crude oil moves along mineraldominated surfaces or naturally occurring depressions, conditions expected on buried pipeline rights-of-way. 3 ) The areal extent of the spill continued to increase until some time after freeze-up, but certainly much longer time periods were required to achieve stability compared with forest area spills. 


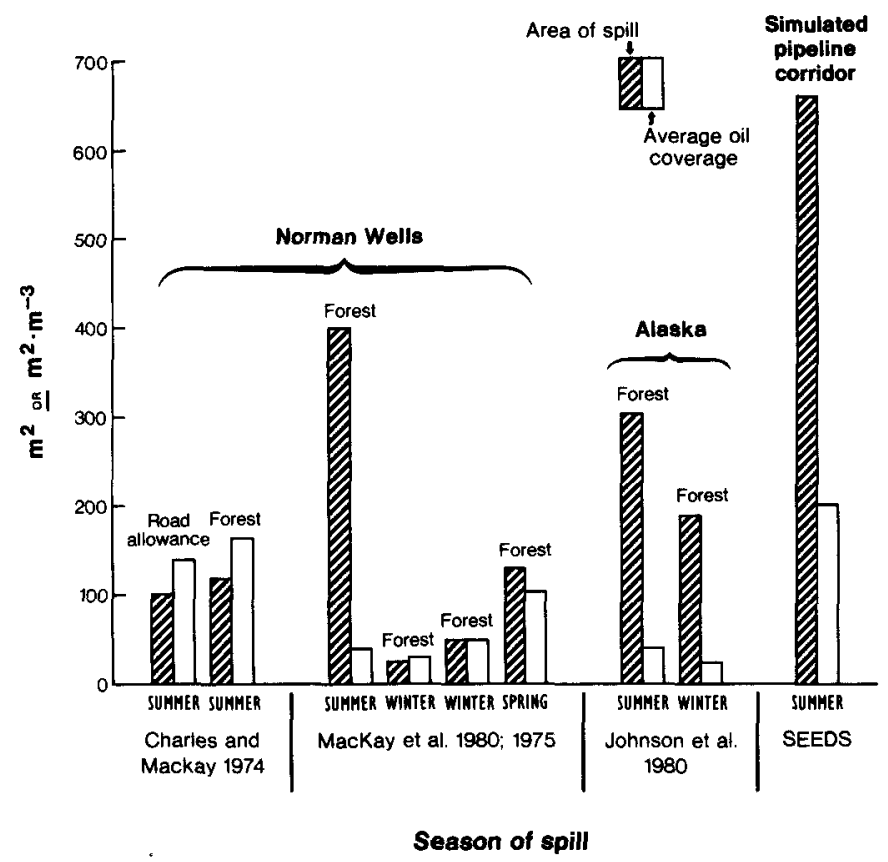

FIG. 4. A comparison of experimental crude-oil spills conducted in subarctic areas. Despite having less than half the oil volume of the Alaskan experiments and one-third the volume of the largest Norman Wells experiment, the SEEDS spill onto a cleared and trenched right-of-way affected the largest surface area.

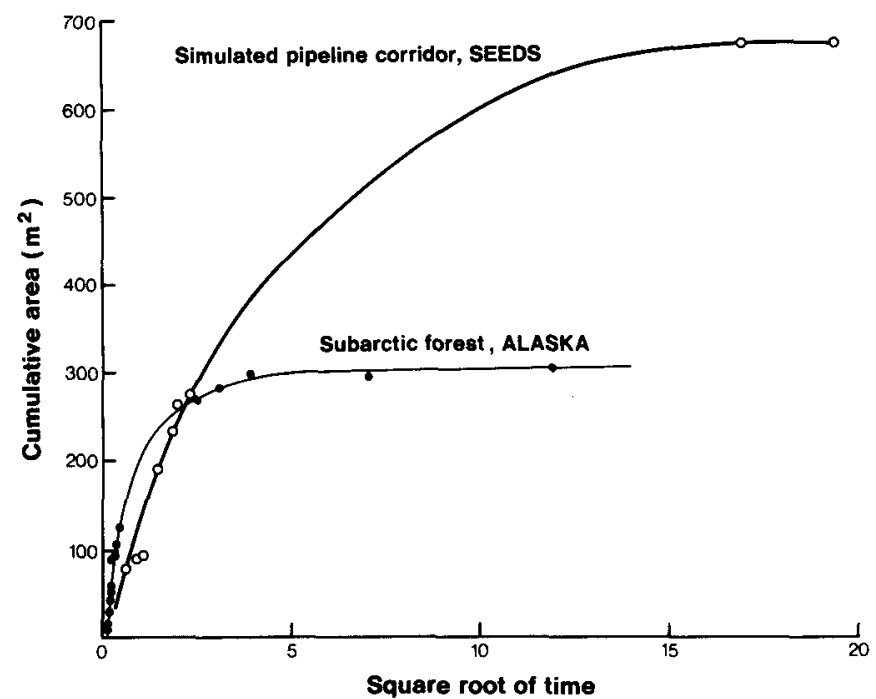

FIG. 5. A comparison of the rate of change in area of experimental crude-oil spills in an undisturbed subarctic forest (Johnson et al.,1980) and on the SEEDS simulated pipeline right-of-way. The spill on the right-of-way took longer to stabilize and covered more than twice the area of the forest spill despite containing less than half the volume used in the Alaskan experiment.

\section{ACKNOWLEDGEMENTS}

Financial assistance for this experiment was provided by the Boreal Institute for Northern Studies (Boreal Alberta Research Grant), Energy Mines and Resources Canada (Research Agreements), ImperialOil Ltd. (University Research Grant), Government of Canada (Student Education and Employment Development Programme), Government of Alberta (Student Temporary Employment Programme) and the Northern Heritage Society/Science Institute of the Northwest Territories (research assistant). I wish to thank Leo
Riendeau, Operations Manager for Interprovincial Pipe Line (NW) Ltd. in Norman Wells, and Don Wishart, Environmental Coordinator in Edmonton, for their help and advice on this research project. Leo also coordinated the winter movement of the oil and provided helicopter transport of researchers and equipment in May as well as a pump with accessories in August. Cal Sikstrom, of Esso Resources Canada, made arrangements with the Norman Wells operation to secure the oil used in the experiment. David Chesterman, Craig Cummings, Kevin Evans, Randy Hetchinelle, Ronald Horassi, Tony $\mathrm{Ng}$ and Michelle Paulsen slickly assisted on site during the deployment of the oil or the spilling operation. Sabine Nolte, Van Le and Kevin Skaret conducted the plane table survey of the spill area in the finest traditions of northern surveyors - swat' $n$ and squint' $n$. The Reprographics Division, Department of Geography, University of Alberta, drafted the cartographic illustrations.

\section{REFERENCES}

CHARLES, M.E., and MACKAY, D. 1974. The rate of flow of oil on land. The Physical Aspects of Crude Oil Spills on Northern Terrain. EnvironmentalSocial Committee, Northern Pipelines, Task Force on Northern Oil Development, Report No. 73-42:72-97. Ottawa: Indian and Northern Affairs.

COLLINS, C.M. 1983. Long-term active layer effects of crude oil spilled in interior Alaska. Permafrost: Fourth International Conference, Proceedings. Washington, D.C.: National Academy Press. 175-179.

EVANS, K.E., KERSHAW, G.P., and GALLINGER, B.J. 1988. Impacts of controlled surface disturbances on active layer and near-surface permafrost in an homogeneous Picea mariana stand, Fort Norman, N.W.T., Canada. Permafrost, Fifth International Conference Proceedings. Trondheim: Tapir. 568-573.

GALLINGER, B.J., and KERSHAW, G.P. 1989. Active layer and geomorphological responses to human-induced disturbances on permafrost-affected terrain. B.C. Geographical Series 46:23-38.

HUTCHINSON, T.C. 1980. Recovery of Arctic and Sub-arctic vegetation nine summers after crude oil and diesel spills. North of 60: Environmental Studies No. 22. Ottawa: Indian and Northern Affairs. 39 p.

and FREEDMAN, W. 1975. Effects of experimental crude oil spills on taiga and tundra vegetation of the Canadian Arctic. Conference on the Prevention and Control of Oil Spills. San Francisco: American Petroleum Institute. 517-525.

1978. Effects of experimental crude oil spills on subarctic boreal forest vegetation near Norman Wells, N.W.T., Canada. Canadian Journal of Botany 56:2424-2433.

HUTCHINSON, T.C., HELLEBUST, J.A., and TELFORD, M. 1974. Oil spill effects on vegetation and soil microfauna at Norman Wells and Tuktoyaktuk, N.W.T. Environmental-Social Committee on Northern Pipelines, Task Force on Northern Oil Development. Report No. R57-10/1974. Ottawa: Information Canada. $143 \mathrm{p}$.

JENKINS, T.F., JOHNSON, L.A., COLLINS, C.M., and McFADDEN, T.T. 1978. The physical, chemical and biological effects of crude oil spills on black spruce forest, interior Alaska. Arctic 31(3):305-323.

JOHNSON, L.A., SPARROW, E.B., JENKINS, T.F., COLLINS, C.M., DAVENPORT, C.V., and McFADDEN, T.T. 1980. The fate and effects of crude oil spilled on subarctic permafrost terrain in interior Alaska. Report 80-29. Hanover, New Hampshire: Cold Regions Research Engineering Laboratory. $67 \mathrm{p}$.

KERSHAW, G.P. 1988. The use of controlled surface disturbances in the testing of reclamation treatments in the Subarctic. In: Kershaw, G.P., ed. Northern Environmental Disturbances. Edmonton: Boreal Institute for Northern Studies. Occasional Publication Number 24:59-70.

and EVANS, K.E. 1987. Soil and near-surface permafrost characteristics in a decadent black spruce stand near Fort Norman, N.W.T. B.C. Geographical Series 44:151-166.

KERSHAW, G.P., and KERSHAW, L.J. 1986. Ecological characteristics of 35year-old crude-oil spills in tundra plant communities of the Mackenzie Mountains, N.W.T. Canadian Journal of Botany 64(12):2935-2947.

MACKAY, D., CHARLES, M.E., and PHILLIPS, C.R. 1974. Physical aspects of crude oil spills on northern terrain (Second Report). Environmental-Social Committee, Northern Pipelines Task Force on Northern Oil Development, Report No. 74-25. Ottawa: Indian and Northern Affairs. 145 p. .1975. The physical aspects of crude oil spills on northern terrain (Final Report). Arctic Land Use Research Program, Report No. 74-25-84. Ottawa: Indian and Northern Affairs. $172 \mathrm{p}$. 
MACKAY, D., WING NG, T., WAN YING SHIU and REUBER, B. 1980. The Degradation of Crude Oil in Northern Soils. Arctic Land Use Research Program, Northern Environmental Protection and Renewable Resources Branch. Ottawa: Department of Indian Affairs and Northern Development. Environmental Studies No. $18.39 \mathrm{p}$.

VIERECK, L.A. 1982. Effects of fire and firelines on active layer thickness and soil temperatures in interior Alaska. Proceedings, Fourth Canadian Permafrost Conference. Ottawa: National Research Council of Canada. 123-147.

WALKER, D.A., WEBBER, P.J., EVERETT, K.R., and BROWN, J. 1978. Effects of crude and diesel oil spills on plant communities at Prudhoe Bay, Alaska, and the derivation of oil spill sensitivity maps. Arctic 31(3):242-259.
WEIN, R.W., and BLISS, L.C. 1973. Experimental crude oil spills on arctic plant communities. Journal of Applied Ecology 10:671-682.

WESTLAKE, D.W.S., JOBSON, A.M., and COOKE, F.D. 1978. In situ degradation of oil in a soil of the boreal region of the Northwest Territories. Canadian Journal of Microbiology 24(3):254-260.

WISHART, D.M. 1988. Reclamation of the Norman Wells Pipeline. In: Kershaw, G.P., ed. Northern Environmental Disturbances. Edmonton: Boreal Institute for Northern Studies, Occasional Publication No. 24:11-26. 